\title{
Originals
}

\section{Hexose specificity for downregulation of HepG2/brain-type glucose transporter gene expression in L6 myocytes}

\author{
F. Maher and L.C. Harrison \\ Burnet Clinical Research Unit, The Walter and Eliza Hall Institute of Medical Research, Royal Melbourne Hospital, Parkville, Victoria, \\ Australia
}

\begin{abstract}
Summary. Glucose deprivation of L6 myocytes results in the upregulation of glucose transporter activity, protein and mRNA. We have investigated the downregulation of transporter gene expression by glucose and other hexoses in glucose-deprived L6 myocytes. Glucose transport activity was measured as the uptake of ${ }^{3} \mathrm{H}$-2-deoxyglucose. Transporter protein and $m$ RNA were detected by immunoblot and Northern blot analysis, respectively, with probes to the rat brain glucose transporter. Glucose deprivation of myocytes, in the absence and presence of insulin, increased ${ }^{3} \mathrm{H}$-2-deoxyglucose uptake, transporter protein and mRNA levels. Refeeding with glucose reversed the glucose deprivation effects on transport activity and mRNA within $12 \mathrm{~h}$, with half-maximal effects at $1-2 \mathrm{mmol} / \mathrm{l}$ glucose. Mannose fully substituted for glucose. Refeeding with the non-metabolisable glucose analogues 2-deoxyglucose and 3-0-methylglucose, or with glucosamine or mannitol, downregulated ${ }^{3} \mathrm{H}-2$-deoxyglucose up-
\end{abstract}

take but had little or no effect on transporter protein and mRNA expression. In contrast, glucose-6-phosphate markedly increased ${ }^{3} \mathrm{H}$-2-deoxyglucose uptake but partly downregulated transporter $m$ RNA levels, whereas galactose had a small stimulatory effect on both ${ }^{3} \mathrm{H}$-2-deoxyglucose uptake and transporter mRNA; neither affected transporter protein levels. The transporter mRNA level was not affected by several metabolites (pyruvate, glyceraldehyde, glycerol) and amino acids (alanine, glutamine). These findingsindicate that (i) there are independent pathways for hexose regulation of transport activity, protein and mRNA and (ii) down-regulation of transporter mRNA requires metabolism beyond hexose phosphate whereas glucose uptake may be regulated by direct interaction of hexoses with the transporter.

Key words: Glucose transporter mRNA, hexose, L6 myocyte.
The facilitated glucose transporter is an integral membrane glycoprotein which mediates the energy-independent transport of glucose across the plasma membrane. The glucose transporter was first cloned from human HepG2 cells [1] and rat brain [2]. While the HepG2/brain-type transporter has been a prototype for studies of transporter gene expression it is now known to belong to a family of related proteins which display tissue specific expression and may be functionally distinct [3-8]. The HepG2/brain-type transporter is regulated at the level of gene and mRNA expression in different physiological states $[9,10]$ by hormones and growth factors [11$15]$ and by hexose availability $[16,17]$.

Glucose deprivation increases glucose transport activity $\left(\mathrm{V}_{\max }\right)$ in a range of cells including myocytes [18-25,2931 , whereas hyperglycaemia or glucose refeeding decreases glucose transport activity [20,26-28]. The glucose deprivation-induced increase in glucose transport is associated with an increase in the number of transporters at the plasma membrane [32] or in the total transporter pool, due either to a decrease in transporter degradation [33] or an increase in transporter biosynthesis [30]. However, hexose regulation of the transporter may occur at the level of protein turnover, independently of changes in translation or transcription, eg. in glucose deprived 3T3-C2 fibroblasts the total amount of transporter protein increased without alteration of the translational efficiency or the amount of transporter mRNA [33]. In cultured glial cells and L6 myocytes glucose deprivation resulted in an increase in the amount of the HepG2/brain-type glucose transporter mRNA which could be reversed by refeeding cells with glucose $[16,17]$. Although other studies have demonstrated that the regulation of glucose transport activity and protein level requires both direct interaction of glucose or other hexose with the transporter and the generation of hexose phosphate $[25,29,33]$, these requirements are not known with respect to the regulation of mRNA expression.

We have used L6 myocytes to investigate the glucosedependent down-regulation of the glucose transport sys- 


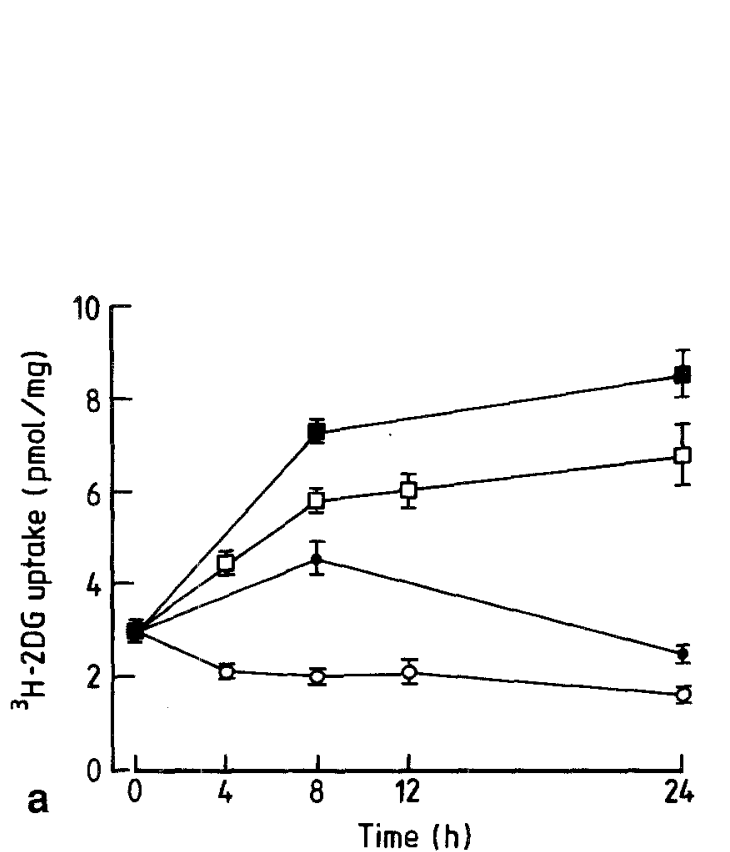

Fig. 1 a-c. Stimulation of ${ }^{3} \mathrm{H}-2 \mathrm{DG}$ uptake, transporter protein and mRNA by glucose deprivation and insulin. L6 myocytes were grown and differentiated in medium containing $5 \mathrm{mmol} / \mathrm{l}$ glucose. At time $=0 \mathrm{~h}$ the medium was changed to either DME containing $5 \mathrm{mmol} / \mathrm{l}$ glucose without (-O-) and with (-) $1 \mu \mathrm{mol} / \mathrm{l}$ insulin or glucose-free DME without ( $\square$ ) or with ( 1 ) $1 \mu \mathrm{mol} / 1$ insulin. ${ }^{3} \mathrm{H}$ 2DG uptake expressed as $\mathrm{pmol} \cdot \mathrm{mg}$ protein ${ }^{-1} \cdot 10 \mathrm{~min}^{-1}$. Each value is the mean $\pm S D$ of 3-6 determinations. $\mathbf{b}$ Northern blot analysis of total RNA ( $25 \mu \mathrm{g} / \mathrm{lane})$ with an oligonucleotide to the rat brain glucose transporter. Glucose transporter mRNA, $2.8 \mathrm{~kb}$. Intensity of the bands was quantified by laser densitometry and plotted as arbitrary densitometer units. c Immunoblot of membrane protein (20 $\mu \mathrm{g} / \mathrm{lane}$ ) with antiserum to the C-terminal peptide of the rat brain glucose transporter. Lane 1, glucose fed, Lane 2, glucose deprived, $24 \mathrm{~h}$. Molecular weight markers are $97,68,43,29$ and $18 \mathrm{kDa}$. The bands at 55,50 and $43 \mathrm{kDa}$ in this preparation are non-specific

tem following glucose deprivation and the hexose specificity and metabolic requirements for regulation of glucose transport activity, protein and mRNA.

\section{Materials and methods}

\section{Cell culture}

Rat L6 myocytes, a subclone of the original L6 line isolated by Yaffe [34], were provided by Dr F. J. Ballard, (CSIRO Division of Human Nutrition, Adelaide, Australia). Myocytes were grown to confluence in Minimal Essential Medium (MEM) ( $5 \mathrm{mmol} / \mathrm{l}$ glucose) containing $10 \%$ fetal calf serum (FCS). Differentiation into multinucleated myotubes was obtained by reducing the FCS to $2 \%$. The medium was changed every 2-3 days until spontaneous contraction of myotubes was observed (usually 8-10 days). Glucose deprivation studies were done with serum-free, glucose-free Dulbecco's modified Eagle medium (DME), with control fed cells in DME containing $5 \mathrm{mmol} / \mathrm{l}$ glucose. Myocytes were viable for up to $48 \mathrm{~h}$ in glucosefree medium. For refeeding, sugars and metabolites were added directly to the medium from $1 \mathrm{~mol} / 1$ stock solutions. Porcine insulin was purchased from CSL-Novo (Melbourne, Australia). Sugars and metabolites were from Sigma (St. Louis. Mo, USA).
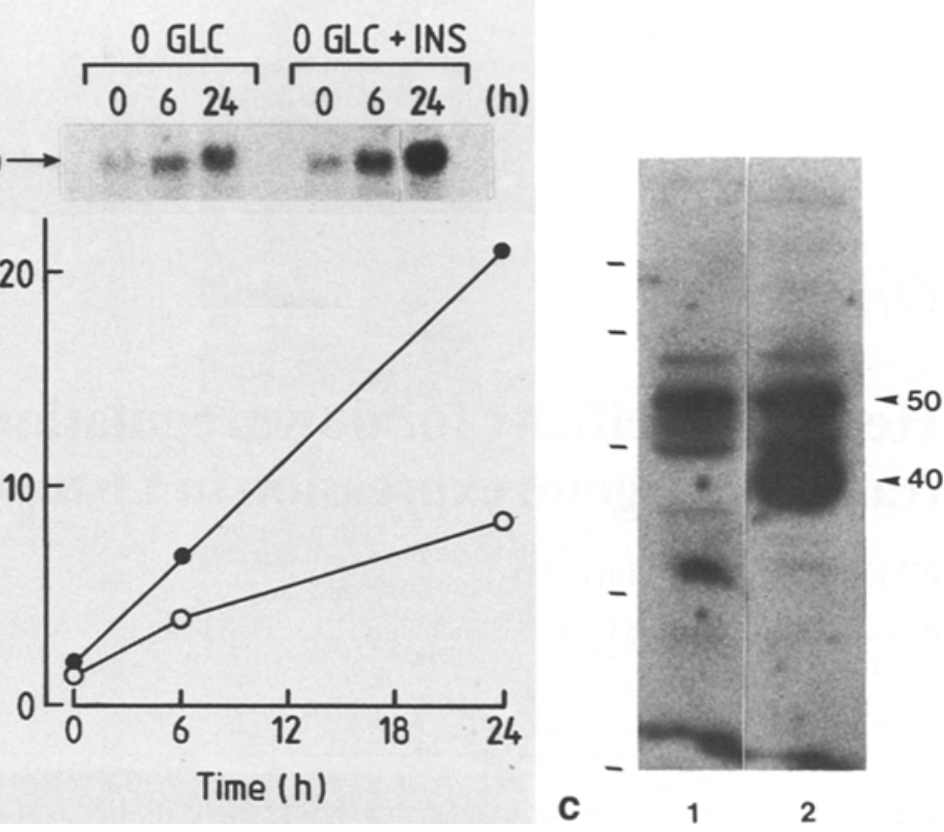

${ }^{3} H$-2-deoxy-D-glucose $\left({ }^{3} H\right.$-2DG) uptake

To determine the rate of ${ }^{3} \mathrm{H}-2 \mathrm{DG}$ uptake cells were washed in glucose free Krebs Ringer bicarbonate buffer with Hanks salts (HKRB) and incubated in $1 \mathrm{ml} \mathrm{HKRB}$ with $3 \mu \mathrm{Ci} 2$-deoxy-D-[1${ }^{3} \mathrm{H}$ ]-glucose (Amersham International, Amersham, UK., $17 \mathrm{Ci} / \mathrm{mmol}$ ) for $10 \mathrm{~min}$ at $37^{\circ} \mathrm{C}$, washed with ice cold phosphate buffered saline (PBS), solubilised in $1 \mathrm{ml}$ of $1 \mathrm{~N} \mathrm{NaOH}$ and counted in a liquid scintillation spectrometer. Non-specific uptake, measured in the presence of cytochalasin B $(50 \mu \mathrm{mol} / 1)$ or phloretin $(500 \mu \mathrm{mol} / \mathrm{l})$, was $\leq 7 \%$ of total uptake and was subtracted from total uptake. ${ }^{3} \mathrm{H}-2 \mathrm{DG}$ uptake is expressed as pmol $\cdot \mathrm{mg}$ cell protein $^{-1} \cdot 10 \mathrm{~min}^{-1}$.

\section{RNA extraction, Northern and slot blotting}

Total cytoplasmic RNA was extracted as previously described [15, $35]$. Cells were resuspended in ice cold lysis buffer $(0.5 \% \mathrm{NP} 40$, $10 \mathrm{mmol} / /$ Tris. $\mathrm{HCl} \mathrm{pH} 7.5,150 \mathrm{mmol} / 1 \mathrm{NaCl}, 2 \mathrm{mmol} / 1 \mathrm{MgCl}_{2}$ ) and the nuclei pelleted at $2000 \mathrm{~g}$ for $5 \mathrm{~min}$ at $4^{\circ} \mathrm{C}$. The lysate was combined with an equal volume of sodium dodecyl sulphate (SDS)/urea solution ( $1 \% \mathrm{SDS}, 7 \mathrm{~mol} / \mathrm{l}$ urea, $350 \mathrm{mmol} / \mathrm{l} \mathrm{NaCl}, 10 \mathrm{mmol} / \mathrm{L}$ EDTA, $100 \mathrm{mmol} / \mathrm{l}$ Tris. $\mathrm{HCl} \mathrm{pH} 7.5)$ and extracted with phenol:chloroform : isoamylalcohol (50:50:1). RNA was quantified by spectrophotometry at $260 \mathrm{~nm}$. For Northern blots, RNA was electrophoresed in $1 \%$ agarose $/ 2.2 \mathrm{~mol} / 1$ formaldehyde gels in MOPS buffer $(20 \mathrm{mmol} / \mathrm{l} 3$-[N-morpholino]propane sulfonic acid, $1 \mathrm{mmol} / 1$ EDTA, $5 \mathrm{mmol} / \mathrm{l}$ sodium acetate $\mathrm{pH} 7.0$ ), stained with ethidium bromide and transferred to nitrocellulose with $20 \times \mathrm{SSC}(3 \mathrm{~mol} / 1$ sodium chloride, $1.3 \mathrm{~mol} / 1$ sodium citrate). For slot blots, RNA was heat denatured $\left(65^{\circ} \mathrm{C}, 15 \mathrm{~min}\right)$ in $2.2 \mathrm{~mol} / 1$ formaldehyde, $5 \times \mathrm{SSC}$, MOPS buffer. Samples were filtered through nitrocellulose and washed with $15 \times \mathrm{SSC}$. Filters were baked in vacuo for $2 \mathrm{~h}$, prehybridised for $4-6 \mathrm{~h}$ in $50 \%$ formamide, $5 \times$ SSC, 5 Denhardt's solution, $500 \mu \mathrm{g} / \mathrm{ml}$ sheared salmon testis DNA and $1 \%$ SDS at $42^{\circ} \mathrm{C}$, and hybridised for $18 \mathrm{~h}$ at $42^{\circ} \mathrm{C}$ in buffer containing ${ }^{32} \mathrm{P}$-labelled probes. Filters were washed for $2 \mathrm{~h}$ in $2 \times \mathrm{SSC} / 0.1 \% \mathrm{SDS}$ at room temperature and $0.2 \times \mathrm{SSC} 0.1 \% \mathrm{SDS}$ at $42^{\circ} \mathrm{C}$ for $30 \mathrm{~min}$, then autoradiographed on Amersham Hyperfilm Multi Purpose (MP). mRNA levels were quantified by scanning the autoradiographs in an LKB Ultroscan laser densitometer (Turku, Finland) and computer fitted integration. Each lane was scanned 2-3 times.

Glucose transporter mRNA (GTmRNA) was detected with an oligonucleotide probe (RGT-1) to the rat brain glucose transporter sequence [2]. RGT-1 is complementary to nucleotides 904-942 with- 
in the cytoplasmic loop region of the transporter. Under the stringency conditions used RGT-1 barely detects GTmRNA in HepG2 cells; the corresponding region of HepG2 transporter sequence (nucleotides $697-735 ;$ [1] differs by 5 nucleotides. It is highly unlikely that this probe would recognize the adipose/muscle glucose transporter which differs by 16 nucleotides in the corresponding region [7], but it may recognize other glucose transporter subtypes which are identical in this region of the RNA sequence. An oligo(dT) 30 mer (TT30) was used for quantification of poly (A) ${ }^{+}$RNA loading on the slot blot shown in Figure 2. Oligonucleotides were 5'-end labelled with $\gamma^{32} \mathrm{P}-\mathrm{ATP}$ and T4 polynucleotide kinase (specific activity $10^{8} \mathrm{cpm} / \mu \mathrm{g}$ ). A cDNA probe to beta-tubulin was labelled with $\alpha-^{32} \mathrm{P}-\mathrm{dATP}$ by random priming (specific activity $10^{9} \mathrm{cpm} / \mu \mathrm{g}$ ).

\section{Membrane preparation and immunoblotting}

Cell membranes were isolated as previously described [36] by incubating cells in hypotonic buffer $(10 \mathrm{mmol} / \mathrm{l}$ Hepes $\mathrm{pH} 7.5,0.5 \mathrm{mmol} / 1$ $\mathrm{MgCl}_{2}$ ) for 30 min at $4{ }^{\circ} \mathrm{C}$, grinding in a Dounce homogeniser and removal of nuclei by centrifugation at $2500 \mathrm{rev} / \mathrm{min}$ for $5 \mathrm{~min}$ at $4^{\circ} \mathrm{C}$. Membranes were pelleted at $13000 \mathrm{rev} / \mathrm{min}$ for $10 \mathrm{~min}$ at $4^{\circ} \mathrm{C}$ and resuspended in $0.1 \mathrm{~mol} / \mathrm{l}$ Tris. $\mathrm{HCl} \mathrm{pH} 6.8,0.1 \mathrm{~mol} / \mathrm{l}$ dithiothreitol, $0.1 \%$ SDS, $10 \%$ glycerol, $0.1 \%$ bromophenol blue. Membrane protein $(25 \mu \mathrm{g})$ was heated at $65^{\circ} \mathrm{C}$ for $5 \mathrm{~min}$ and size fractionated, along with BioRad prestained high molecular weight markers, in $10 \%$ SDS-polyacrylamide gels in the Hoefer Mighty Small electrophoresis system and transferred to nitrocellulose in an LKB Novablot electrophoretic transfer kit. Filters were blocked for $2 \mathrm{~h}$ with phosphate buffered saline (PBS) containing $0.05 \%$ Tween 20 (PBS/Tween) and $5 \%$ milk powder then incubated for $12 \mathrm{~h}$ at $4{ }^{\circ} \mathrm{C}$ with PBS/Tween $/ 1 \%$ BSA containing antiserum. Filters were then washed, incubated in $5 \mathrm{ml} \mathrm{PBS} /$ Tween $/ 1 \% \mathrm{BSA}$ containing $1 \mu \mathrm{Ci}$ ${ }^{125} \mathrm{I}$-protein $\mathrm{A}$ for $1 \mathrm{~h}$ at room temperature, washed in PBS $/ 0.2 \%$ Tween and autoradiographed. Glucose transporter protein was detected with a 1/200 dilution of a rabbit antiserum raised against the C-terminal peptide (amino acids 480-492) of the rat brain glucose transporter [37]. It is unlikely that this antiserum would detect the adipose/muscle-type glucose transporter which has no homology in the C-terminal amino acid sequence [7] but it may recognise other glucose transporter subtypes with similar $\mathrm{C}$-terminal sequence. For antibody blocking experiments undiluted antiserum was incubated for $1 \mathrm{~h}$ at room temperature with $0.1 \mathrm{mg} / \mathrm{ml}$ C-terminal peptide. Transporter protein was quantified by scanning densitometry of the autoradiographs.

\section{Results}

\section{Stimulation of glucose transporter activity, protein and $m R N A$ expression by glucose deprivation and insulin}

In order to investigate hexose-dependent regulation of glucose transporter gene expression we first confirmed that glucose deprivation caused induction of the glucose transporter system in this subclone of L6 myocytes. The results are similar to those reported by Walker et al. [17]. Chronic glucose deprivation caused time-dependent stimulation of the rate of ${ }^{3} \mathrm{H}-2 \mathrm{DG}$ uptake (four-fold) (Fig. 1a) and increased levels of HepG2/brain-type glucose transporter mRNA (two- to four-fold) (Fig. 1b) and protein (ten-fold) (Fig. 1c). In control glucose-fed cells antiserum to the $\mathrm{C}$-terminal peptide of the rat brain transporter detected a low abundance protein which migrated as a diffuse band with apparent molecular weight of 4550 kilodalton (kDA) (Fig. 1c). In glucose-deprived cells there was no consistent change in the amount of 45$50 \mathrm{kDA}$ transporter but a sharp protein band with appar-
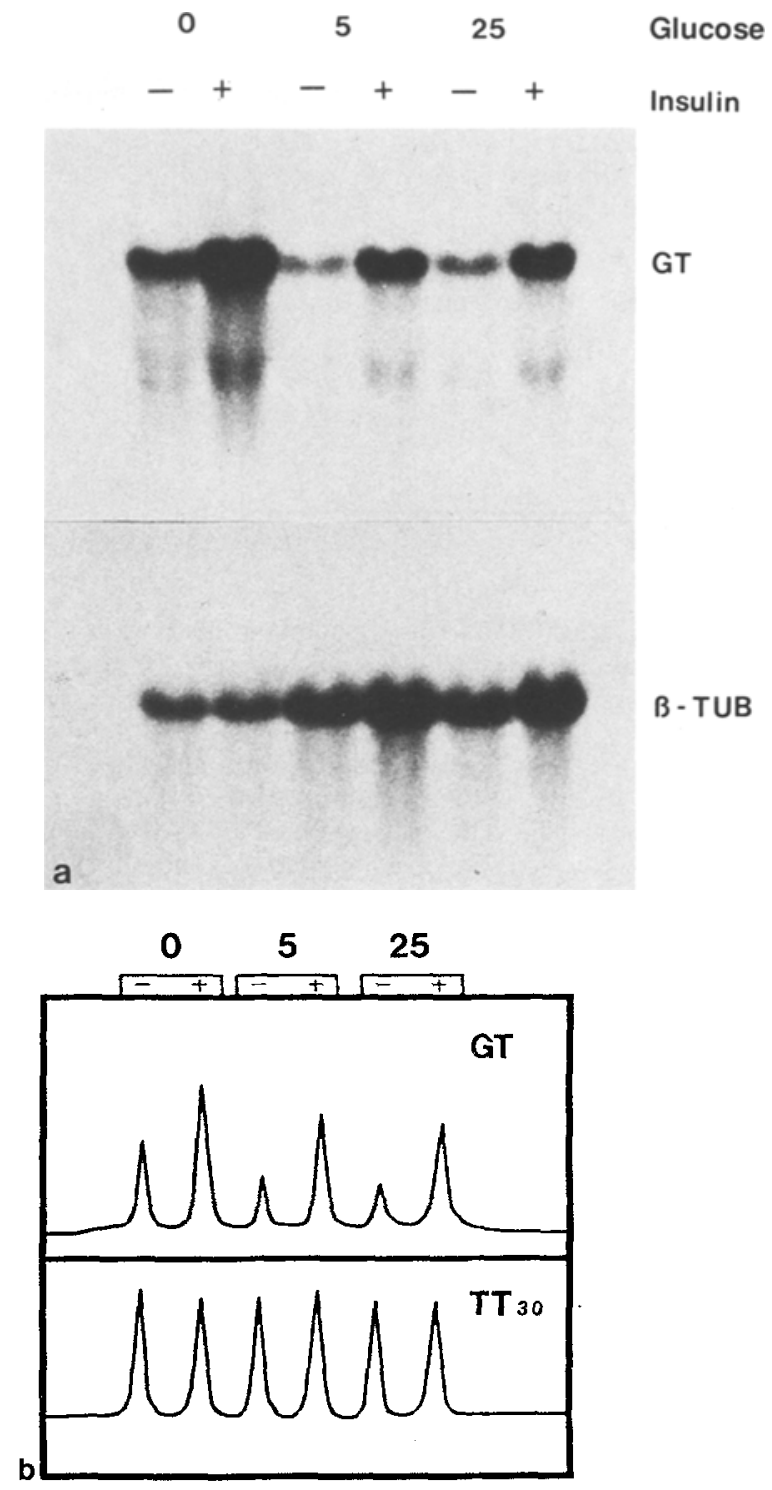

Fig. 2 a, b. Effect of glucose concentration on insulin stimulation of GTmRNA expression. L6 myocytes were grown and differentiated in $5 \mathrm{mmol} / \mathrm{l}$ glucose then incubated for $18 \mathrm{~h}$ in medium containing 0 , 5 or $25 \mathrm{mmol} / \mathrm{l}$ glucose without $(-)$ or with $(+) 1 \mu \mathrm{mol} / \mathrm{l}$ insulin. a Northern blot analysis ( $20 \mu \mathrm{g}$ total RNA) with an oligonucleotide to the rat brain glucose transporter (GT) and beta-tubulin (betaTUB). b Representative slot blot hybridised for glucose transporter and with an oligo(dT) probe (TT30) to measure poly $(\mathrm{A})^{+}$RNA loading. RNA was quantified by laser densitometry. The blots are representative of three independent experiments

ent molecular weight of $40 \mathrm{kDa}$ appeared. Detection of both the $45-50 \mathrm{kDa}$ and the $40 \mathrm{kDa}$ proteins was blocked by pre-incubating the antiserum with excess C-terminal peptide. In some preparations such as the one shown in Figure $1 \mathrm{c}$ a strong non-specific band (not blocked by excess C-terminal peptide) was evident at $50 \mathrm{kDa}$. These transporter proteins differ from the 43 and $46 \mathrm{kDa}$ doublet detected previously in glucose-deprived L6 myocytes with antiserum to the erythrocyte glucose transporter [17]. Exposure of glucose-deprived cells to insulin $(1 \mu \mathrm{mol} / \mathrm{l})$ further stimulated ${ }^{3} \mathrm{H}-2 \mathrm{DG}$ uptake by $25-30 \%$, and the $40 \mathrm{kDa}$ glucose transporter and mRNA five-fold. 


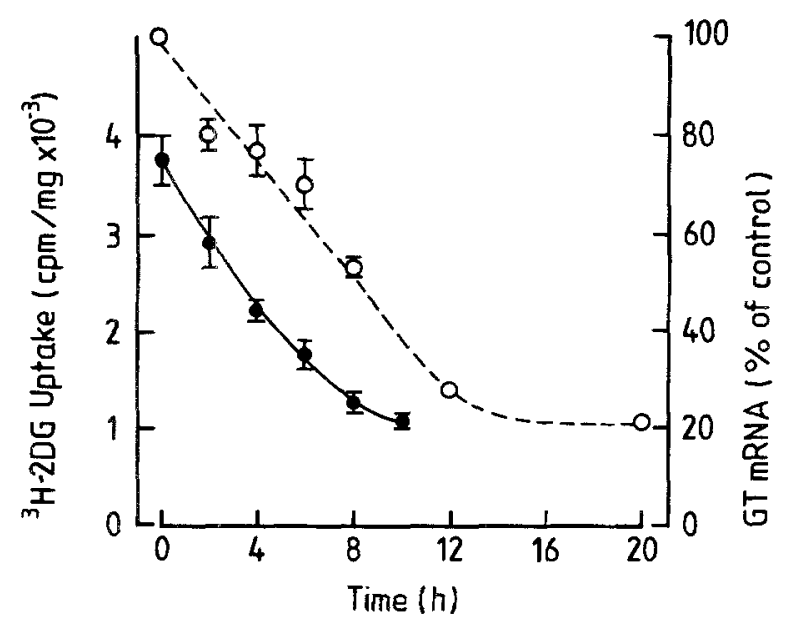

Fig.3. Time course effect of glucose refeeding on ${ }^{3} \mathrm{H}-2 \mathrm{DG}$ uptake and GTmRNA expression. Myocytes were incubated in glucosefree medium containing $1 \mu \mathrm{mol} / \mathrm{l}$ insulin for $12 \mathrm{~h}$ to stimulate transporter expression. At time $=0$, the medium was supplemented with glucose $(20 \mathrm{mmol} / \mathrm{h}) .{ }^{3} \mathrm{H}-2 \mathrm{DG}$ uptake was measured and $\mathrm{mRNA}$ extracted at times up to $20 \mathrm{~h} .{ }^{3} \mathrm{H}-2-\mathrm{DG}$ uptake $(-)$ ) is expressed as $\mathrm{cpm} / \mathrm{mg}$ protein. Each value is the mean $\pm \mathrm{SD}$ of triplicate determinations. GTmRNA values (O--O) are obtained from densitometry of three Nothern blots probed with an oligonucleotide to the rat brain glucose transporter. Results (arbitrary units) are expressed as $\%$ of control (time $=0 \mathrm{~h}$ ) and each value is the mean $\pm \mathrm{SD}$

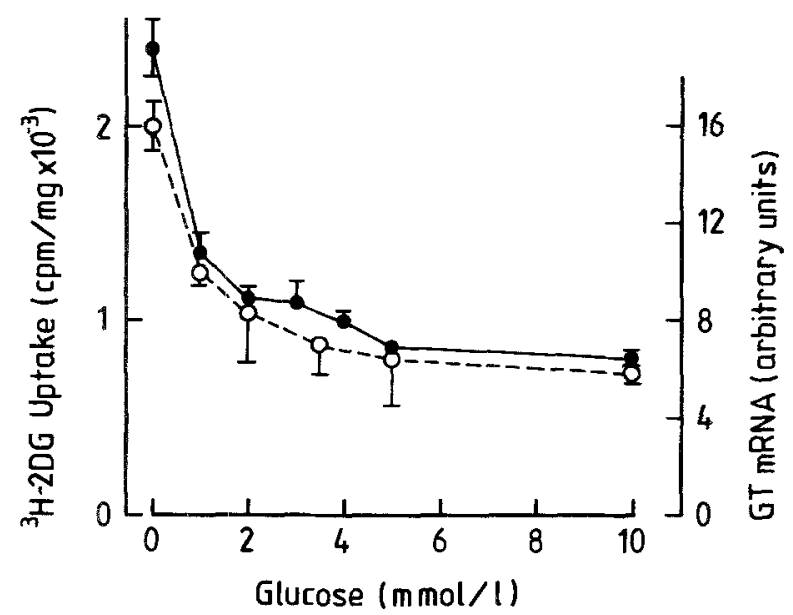

Fig. 4. Dose response effect of glucose refeeding on ${ }^{3} \mathbf{H}-2 \mathrm{DG}$ uptake and GTmRNA expression. Myocytes were incubated in glucosefree medium containing $1 \mu \mathrm{mol} / \mathrm{l}$ insulin for $12 \mathrm{~h}$ to stimulate transporter expression. Glucose was added at concentrations up to $10 \mathrm{mmol} / \mathrm{l}$, incubation proceeded for $12 \mathrm{~h}$ and ${ }^{3} \mathrm{H}-2 \mathrm{DG}$ uptake and GTmRNA levels were measured. ${ }^{3} \mathrm{H}-2 \mathrm{DG}$ uptake values $(-)$, expressed as $\mathrm{cpm} / \mathrm{mg}$ protein, are the mean \pm SD of triplicate determinations. GTmRNA values $(\mathrm{O}--\mathrm{O})$ ) are the mean \pm SD (arbitrary densitometer units) of three Northern blots probed with an oligonucleotide to the rat brain glucose transporter, quantified by laser densitometry

\section{Effect of glucose concentration on insulin-stimulated glucose transporter expression}

Previously we found that insulin and IGF-1 stimulated glucose transporter mRNA expression in L6 myocytes at the standard medium glucose concentration of $5 \mathrm{mmol} / 1$ [15]. The experiments shown in Figure 2 directly compare the effects of $1 \mu \mathrm{mol} / \mathrm{l}$ insulin, at different glucose concentrations, on GTmRNA expression. Insulin stimulated GTmRNA levels approximately five times both in the absence of glucose and in the presence of $5 \mathrm{mmol} / 1$ or $25 \mathrm{mmol} / \mathrm{l}$ glucose. This increase in GTmRNA was evident when compared to the amount of poly $(\mathrm{A})^{+} \mathrm{RNA}$ loaded (Fig. 2 b) and was independent of changes in betatubulin expression which was decreased in glucose deprived cells and increased ( $\sim$ two-fold) by insulin in fed cells but not in glucose deprived cells (Fig. 2 a). Thus, glucose deprivation prevented the stimulatory effect of insulin on beta-tubulin mRNA but not on GTmRNA. These data suggest that the glucose concentration does not alter the ability of insulin to stimulate GTmRNA expression.

\section{Reversal of the glucose deprivation effects on glucose transporter activity and $m R N A$ by glucose: time course and dose response}

Following induction of L6 myocyte glucose transporter expression by glucose deprivation a second incubation was performed in the same medium with or without glucose. Qualitatively the same results were obtained with or without insulin in the medium. The increase in both ${ }^{3} \mathrm{H}$ 2DG uptake and GTmRNA levels was reversed by glucose in a time- and concentration-dependent manner. The rate of ${ }^{3} \mathrm{H}-2 \mathrm{DG}$ uptake and the amount of GTmRNA decreased in parallel, with a $50 \%$ decrease in $6-8 \mathrm{~h}$ reaching basal levels in $12-14 \mathrm{~h}$ (Fig.3). The concentration-dependence for glucose reversal of ${ }^{3} \mathrm{H}-2 \mathrm{DG}$ uptake and GTmRNA was the same, the half-maximal decrease occurring with $1-2 \mathrm{mmol} / \mathrm{l}$ glucose and maximal decrease at $5 \mathrm{mmol} / \mathrm{l}$ glucose (Fig. 4 ).

\section{Hexose specificity for downregulation of glucose transporter expression}

A range of glucose analogues, sugars and metabolites was examined for the ability to replace glucose in the downregulation of glucose transporter expression. The ability of hexoses to compete with ${ }^{3} \mathrm{H}-2 \mathrm{DG}$ uptake in $\mathrm{L} 6$ myocytes has been described $[18,38]$.

Myocytes were incubated in glucose-free medium containing insulin followed by chronic exposure to hexose. ${ }^{3} \mathrm{H}-2 \mathrm{DG}$ uptake was downregulated to a similar extent $(40-60 \%)$ by glucose, 2-deoxyglucose, mannose, 3-O-methylglucose and mannitol (Table 1). Galactose caused a small increase in ${ }^{3} \mathrm{H}-2 \mathrm{DG}$ uptake, whereas glucosamine markedly reduced the rate of glucose uptake (by $80 \%$ ). Glucose-6-phosphate upregulated (by $66 \%$ ) the rate of ${ }^{3} \mathrm{H}-2 \mathrm{DG}$ uptake. Sucrose had no significant effect.

Refeeding with glucose and mannose reversed the induction of the $40 \mathrm{kDa}$ transporter species and caused a small increase in the amount of the $45-50 \mathrm{kDa}$ transporter species (Fig.5), but the total amount of transporter in refed cells $(40 \mathrm{kDa}+45-50 \mathrm{kDa}$ species) was less than the total amount of $40 \mathrm{kDa}$ transporter in glucose-deprived cells. Galactose alone had no effect on transporter 


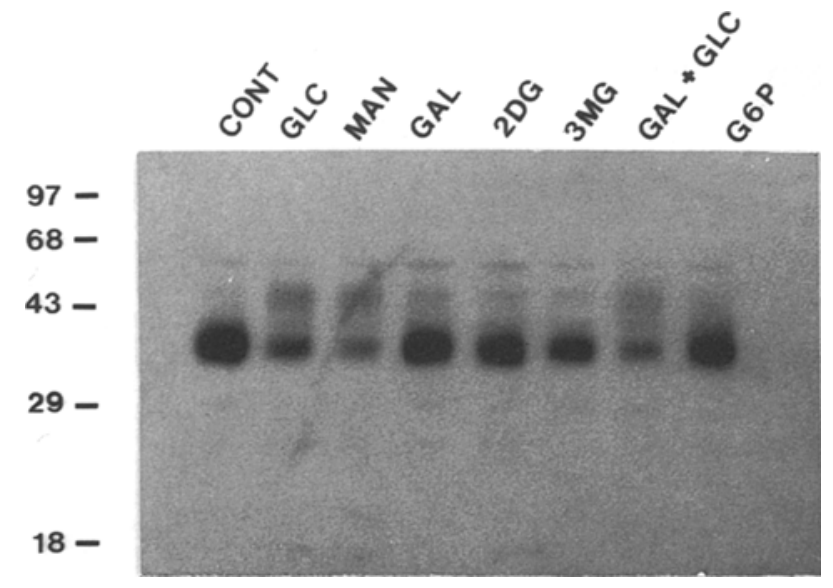

Fig.5. Downregulation of transporter protein expression. Myocytes were incubated in glucose-free medium containing $1 \mu \mathrm{mol} / 1$ insulin for $12 \mathrm{~h}$ to stimulate transporter expression. Hexose $(20 \mathrm{mmol} / \mathrm{l})$ was added to the medium and incubation continued for $12 \mathrm{~h}$. Membranes $(25 \mu \mathrm{g})$ were analysed by immunoblotting with antiserum to the rat brain glucose transporter C-terminal peptide. CONT, no hexose; GLC, glucose; MAN, mannose; GAL, galactose; 2DG, 2-deoxyglucose; 3MG, 3-O-methylglucose; G6P, glucose-6-phosphate. Molecular weight markers $(\mathrm{kDa})$ are shown on the left. Glucose deprivation and incubation with 3-0-methylglucose resulted in a $20-30 \%$ decrease in membrane recovery. Ineubation with other hexose for $12 \mathrm{~h}$ had no significant effect on membrane recovery

protein levels and, when present with glucose, did not prevent the downregulation by glucose (Fig. 5). Incubation of cells with 2-deoxyglucose and 3-0-methylglucose caused a small decrease in the amount of $40 \mathrm{kDa}$ transporter, but this was not sufficient to account for the extent of downregulation of ${ }^{3} \mathrm{H}-2 \mathrm{DG}$ uptake. Glucose-6-phosphate (Fig.5) and sucrose (not shown) had no significant effect on the amount of the $40 \mathrm{kDa}$ transporter.

GTmRNA was downregulated equally by glucose and mannose, and to a lesser extent by glucose-6-phosphate (Fig. 6). 2-deoxyglucose and 3-O-methylglucose did not significantly alter expression of GTmRNA. Galactose and glucosamine, on the other hand, further increased GTmRNA levels by $\sim 30 \%$, but galactose was unable to prevent the decrease caused by glucose or mannose. Mannitol and sucrose had no effect on GTmRNA levels (not shown). As 2-deoxyglucose, which is transported and phosphorylated, could not replace glucose in the downregulation of glucose transporter protein and $\mathrm{mRNA}$ expression, these results indicate that neither direct interaction with the transporter nor generation of hexose phosphate is sufficient to downregulate transporter mRNA and protein, suggesting that a metabolic intermediate beyond the level of glucose-6-phosphate is required. Therefore, other nutrients and metabolic substrates were tested for their ability to downregulate GTmRNA expression. The culture medium (glucosefree DME) contains pyruvate $(1 \mathrm{mmol} / \mathrm{l})$, glutamine $(2 \mathrm{mmol} / \mathrm{l})$ and other amino acids, but not alanine. Clearly, the presence of these nutrients did not prevent the induction of GTmRNA expression. Addition of excess pyruvate $(10 \mathrm{mmol} / \mathrm{l})$ and of alanine $(10 \mathrm{mmol} / \mathrm{l})$, glycerol $(10 \mathrm{mmol} / 1)$ or glyceraldehyde $(2 \mathrm{mmol} / \mathrm{l})$ did not reverse the effect of glucose deprivation (data not shown). Higher concentrations of glyceraldehyde $(\geq 5 \mathrm{mmol} / \mathrm{l})$ caused loss of cell viability and a decrease in extractable intact RNA and therefore could not be tested for effects on GTmRNA.

Selective regulation of GTmRNA was indicated by the observation that beta-tubulin mRNA expression was altered in the opposite direction to GTmRNA. Glucose deprivation decreased the amount of beta-tubulin mRNA (Fig.2). Refeeding with glucose, mannose and glucose-6phosphate, which downregulated GTmRNA expression, increased beta-tubulin mRNA levels (Fig. 6). Other sugars and metabolites, which did not substitute for glucose in the downregulation of GTmRNA levels, failed to increase beta-tubulin expression. Thus, there was an inverse correlation between hexose regulation of GTmRNA and beta-tubulin mRNA levels.

\section{Discussion}

Our finding that glucose deprivation, either in the absence or presence of insulin/IGF-1, stimulates expression of the HepG2/brain-type glucose transporter at the level of mRNA in differentiated L6 myocytes confirms the report of Walker et al. [17], although some differences are apparent; for example, we detect the induction of a $40 \mathrm{kDa}$ glucose transporter protein with an anti-C-terminal antiserum whereas Walker et al. [17] detect a doublet of 43 and $46 \mathrm{kDa}$ with an anti-human erythrocyte transporter antiserum. Furthermore, in our experiments a discrepancy exists in $\mathrm{L} 6$ cells between the effects of insulin on the levels of protein and mRNA (elevated five- to tenfold) compared to transporter activity (enhanced by only $20-30 \%$ ) in glucose-deprived cells. Studies in human fibroblasts [39] and rat soleus muscle [20] have also shown failure of insulin to significantly stimulate glucose uptake in the glucose-deprived state. The discrepancy could be due to differential regulation by glucose deprivation and

Table 1. Hexose regulation of ${ }^{3} \mathrm{H}-2 \mathrm{DG}$ uptake

\begin{tabular}{lll}
\hline Hexose & \multicolumn{2}{l}{${ }^{3} \mathrm{H}-2 \mathrm{DG}$ uptake } \\
\cline { 2 - 3 } & (pmol/well $\pm \mathrm{SD})$ & $\%$ of control \\
\hline Glucose $5 \mathrm{mmol} / \mathrm{l}$ & $1.07 \pm 0.08$ & \\
No hexose $8 \mathrm{~h}$ & $2.44 \pm 0.20$ & \\
No hexose $20 \mathrm{~h}$ & $2.71 \pm 0.20$ & 100 \\
Glucose $5 \mathrm{mmol} / \mathrm{l}$ & $1.91 \pm 0.16$ & 70 \\
Glucose $25 \mathrm{mmol} / \mathrm{l}$ & $1.62 \pm 0.07$ & 60 \\
2-deoxyglucose & $1.18 \pm 0.08$ & 44 \\
3-O-methylglucose & $1.46 \pm 0.03$ & 54 \\
Mannose & $1.36 \pm 0.08$ & 50 \\
Galactose & $3.04 \pm 0.20$ & 112 \\
Glucose-6-P & $4.50 \pm 0.36$ & 166 \\
Mannitol & $1.96 \pm 0.12$ & 72 \\
Glucosamine & $0.50 \pm 0.02$ & 18 \\
Sucrose & $2.25 \pm 0.13$ & 83 \\
\hline
\end{tabular}

Myocytes were incubated for $8 \mathrm{~h}$ in glucose-free medium containing $1 \mu \mathrm{mol} / \mathrm{l}$ insulin. At $8 \mathrm{~h}$, glucose $(5 \mathrm{and} 25 \mathrm{mmol} / \mathrm{l})$ and other hexoses ( $25 \mathrm{mmol} / \mathrm{l})$ were added directly to the medium. Incubation continued for $12 \mathrm{~h}$ prior to measurement of ${ }^{3} \mathrm{H}-2 \mathrm{DG}$ uptake. Results are the mean $\pm \mathrm{SD}$ of triplicate determinations expressed as pmol/well and as \% of control (no hexose, $20 \mathrm{~h}$ ) 


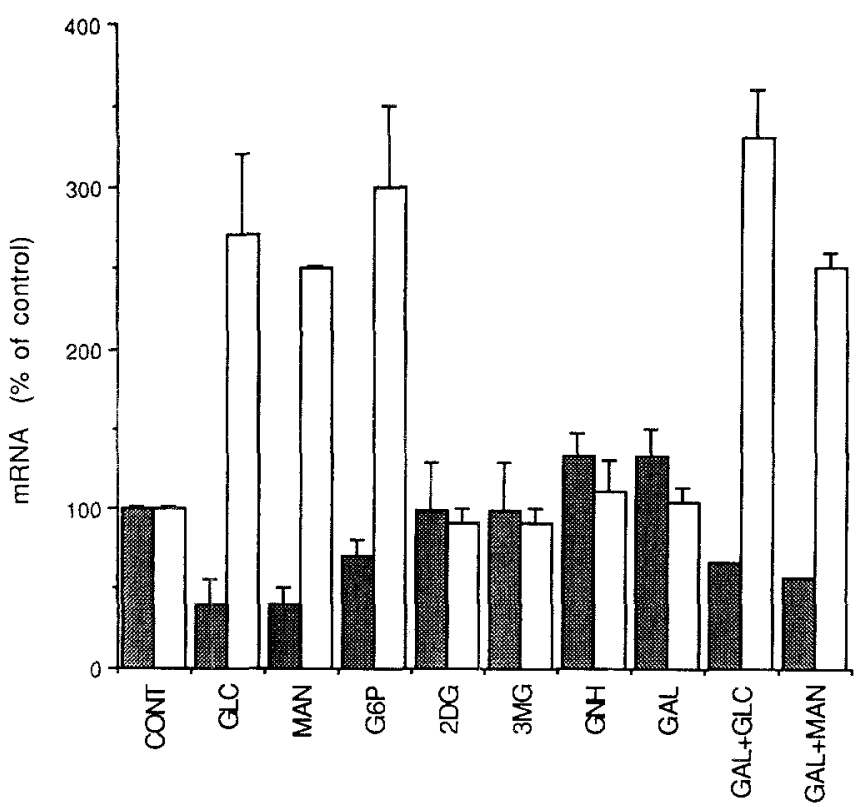

Fig. 6. Downregulation of GTmRNA expression. Myocytes were incubated in glucose-free medium containing $1 \mu \mathrm{mol} / \mathrm{l}$ insulin for $12 \mathrm{~h}$, then the indicated hexose $(20 \mathrm{mmol} / \mathrm{l})$ was added directly to the medium and incubation continued for $12 \mathrm{~h}$. Total RNA $(25 \mu \mathrm{g})$ was analysed by slot or Northern blot hybridisation with an oligonucleotide to the rat brain glucose transporter (shaded) and beta-tubulin cDNA (unshaded). Autoradiographs were quantified by laser densitometry and the values expressed as \% of control. The values are the mean $\pm S D$ for each substance tested 2-4 times. CONT, no addition; GLC, glucose; MAN, mannose; G6P, glucose-6-phosphate; 2DG, 2 deoxyglucose; 3MG, 3-O-methylglucose; $\mathrm{GNH}$, glucosamine; GAL, galactose

insulin of different transporter populations or subtypes. Another interpretation is that a post-translational defect develops during glucose deprivation, such that maximal stimulation of transporter protein synthesis by insulin is not realized at the level of glucose transport activity. This may be due to partial glycosylation of the glucose transporter [33, 40-43], interference with post-translation processing or insertion of transporters in the plasma membrane in the glucose-deprived state.

\section{Independent regulation of glucose transporter activity, protein and $m R N A$ levels by various hexoses}

The downregulation of ${ }^{3} \mathrm{H}-2 \mathrm{DG}$ uptake by glucose and mannose was paralleled by decreases in GTmRNA and $40 \mathrm{kDa}$ transporter protein levels (Table 2), implying that the decrease in transport activity is directly due to the decrease in transporter transcription or mRNA stability and translation. Previous studies have shown glucose and mannose dependent downregulation of glucose uptake $[17,25,29,45]$ and transporter protein [33]. In a study on glial cells [16] the glucose deprivation-induced expression of glucose transporter activity and mRNA was also shown to be reversed by glucose, but the hexose specificity was not addressed. We find that hexoses other than glucose and mannose cause changes in glucose transport activity without altering glucose transporter protein and $\mathrm{mRNA}$ expression (Table 2). Thus, 2-deoxyglucose, 3-O-methylglucose, glucosamine and mannitol downregulated ${ }^{3} \mathrm{H}$ $2 D G$ uptake, as described previously in fibroblasts $[46,47]$ and 3T3 adipocytes [25], but these hexoses did not downregulate GTmRNA levels. On the assumption that most of the glucose transport activity in these cells is due to the HepG2/brain-type transporter, this suggests that direct interaction of hexose with the transporter is able to regulate the intrinsic activity or membrane distribution of transporters, independent of changes in transporter transcription and translation. However, regulation of transport activity is complex because glucosamine and mannitol, which are poor competitors of glucose uptake in L6 myocytes $[18,38]$, downregulated ${ }^{3} \mathrm{H}-2 \mathrm{DG}$ uptake whereas galactose did not, consistent with previous reports [23, $25]$. We are unable to directly assess the contribution of other transporter species to glucose uptake and therefore it remains possible that different glucose transporter subtypes are regulated independently by different hexoses.

The direct effect of hexose on regulation of transporter activity is also indicated by the effects of glucose-6phosphate, which markedly increased transport activity while causing a small decrease of GTmRNA levels. Glucose-6-phosphate increases cytochalasin $B$ binding to the glucose transporter in L6 myocytes [48], possibly in an allosteric manner, and may therefore enhance glucose recognition and transporter activity. As glucose-6-phosphate did not compete directly for ${ }^{3} \mathrm{H}-2 \mathrm{DG}$ uptake, we assume that it is not transported into the cell. However, a small amount of glucose-6-phosphate transported, or degraded by membrane phosphatases to glucose, may account for the small decrease in GTmRNA levels and the reciprocal increase in beta-tubulin mRNA levels.

\section{Hexose/nutrient requirements for downregulation of glucose transporter $m R N A$ and protein}

Reversal of the glucose deprivation effect on GTmRNA and $40 \mathrm{kDa}$ transporter apparently requires both direct interaction with the transporter and metabolism beyond the level of hexose phosphate and/or maintenance of normal glycoprotein synthesis. Glucose and mannose were the only hexoses able to maximally downregulate GTmRNA and protein following glucose deprivation.

Table 2. Comparison of hexose effects on glucose transporter activity, protein and mRNA

\begin{tabular}{llll}
\hline Glucose deprivation & 3H-2DG & $40 \mathrm{kDa}$ & GTmRNA \\
& Uptake & Transporter & $\uparrow$ \\
& $\uparrow$ & $\uparrow$ & $\uparrow$ \\
\hline Glucose & $\downarrow \downarrow$ & $\downarrow \downarrow$ & $\downarrow \downarrow$ \\
Mannose & $\downarrow \downarrow$ & $\downarrow \downarrow$ & $\downarrow \downarrow$ \\
Glucose-6-phosphate & $\uparrow \uparrow$ & - & $\downarrow$ \\
2-Deoxyglucose & $\downarrow \downarrow$ & $-/ \downarrow$ & - \\
3-O-Methylglucose & $\downarrow \downarrow$ & $-/ \downarrow$ & - \\
Galactose & $-/ \uparrow$ & - & $\uparrow$ \\
Glucosamine & $\downarrow \downarrow \downarrow$ & - & $\uparrow$ \\
Mannitol & $\downarrow \downarrow$ & ND & - \\
Sucrose & - & - & - \\
\hline
\end{tabular}

$\uparrow$ Increase; $\downarrow$ decrease; - no change; ND: not done 
Both hexoses are equally good substrates for the transporter in L6 myocytes, are essentially interchangeable as substrates for glycolysis [49] and support normal glycoprotein synthesis. An increase in the amount of the $50 \mathrm{kDa}$ transporter species after refeeding with glucose and mannose is consistent with glycosylation of some of the $40 \mathrm{kDa}$ transporter species, although the total level of transporter protein remained decreased. The use of non-metabolisable glucose analogues 2-deoxyglucose and 3-0-methylglucose, which are transported by the glucose transporter but do not significantly downregulate GTmRNA or protein levels, demonstrates that neither direct interaction of hexose with the glucose transporter nor production of hexose phosphate is sufficient to reverse the glucose deprivation effects. Therefore, it seems that metabolism of glucose beyond hexose phosphate is required to downregulate expression of the HepG2/brain glucose transporter mRNA and protein.

Other hexose and metabolic substrates tested could not substitute for glucose and mannose in the downregulation of GTmRNA and protein. The inability of glyceraldehyde, pyruvate, glycerol and amino acids to prevent or reverse the glucose deprivation effect on GTmRNA indicates that GTmRNA expression in L6 myocytes is not regulated directly by these metabolites and is independent of general energy metabolism, consistent with the findings for the regulation of glucose transporter accumulation in 3T3-C2 cells [33]. Other potential regulators include pentose pathway intermediates, not tested in this study, which appear to be involved in the regulation of glucose transport in a mutant fibroblast cell line deficient in phosphoglucose isomerase [47]. In a detailed study of hexose regulation of glucose transporter protein accumulation in 3T3-C2 fibroblasts Haspel et al. [33] concluded that both substrate interaction with the glucose transporter and hexose phosphate metabolism or accumulation regulate the effects of glucose deprivation and refeeding. However, in this cell line no change was observed in the rate of translation or the amount of HepG2/brain glucose transporter mRNA, indicating that transporter accumulation was regulated by protein turnover. There are, therefore, cell-specific and hexose-specific pathways for regulation of the glucose transporter system at the levels of transcription or mRNA stability, translation, protein turnover and transporter activity.

Acknowledgements. We thank Dr. I. A.Simpson for providing the glucose transporter antiserum, Dr. G. Tregear for synthesizing the oligonucleotide probes and Dr. S. Clark for comments on the manuscript and helpful discussion. Ms. M. Thompson provided secretarial assistance.

\section{References}

1. Mueckler M, Caruso C, Baldwin SA, Panico M, Blench I, Morris HR, Allard WJ, Lienhard GE, Lodish HF (1985) Sequence and structure of a human glucose transporter. Science 229 : 941-945

2. Birnbaum MJ, Haspel HC, Rosen OM (1986) Cloning and characterization of a cDNA encoding the rat brain glucose-transporter protein. Proc Natl Acad Sci USA 83: 5784-5788

3. Kayano T, Fukumoto H, Eddy RL, Fan Y-S, Byers MG, Shows TB, Bell GI (1988) Evidence for a family of human glucose trans- porter-like proteins. Sequence and gene localization of a protein expressed in fetal skeletal muscle and other tissues. J Biol Chem 263: 15245-15248

4. Fukumoto H, Seino S, Imura H, Seino Y, Eddy RL, Fukushima Y, Byers MG, Shows TB, Bell GI (1988) Sequence, tissue distribution, and chromosomal localization of mRNA encoding a human glucose transporter-like protein. Proc Natl Acad Sci USA 85: 5434-5438

5. Thorens B, Sarkar HK, Kaback HR, Lodish HF (1988) Cloning and functional expression in bacteria of a novel glucose transporter present in liver, intestine, kidney and $\beta$-pancreatic islet cells. Cell 55:281-290

6. Charron MJ, Brosius FC III, Alper SL, Lodish HF (1989) A glucose transport protein expressed predominantly in insulin-responsive tissues. Proc Natl Acad Sci USA 86: 2535-2539

7. James DE, Strube M, Mueckler M (1989) Molecular cloning and characterisation of an insulin-regulatable glucose transporter. Nature 338: 83-87

8. Herreros AG de, Birnbaum MJ (1989) The acquisition of increased insulin-responsive hexose transport in 3T3-L1 adipocytes correlates with expression of a novel transporter gene. $J$ Biol Chem 264: 19994-19999

9. Berger J, Biswas C, Vicario PP, Strout HV, Saperstein R, Pilch PF (1989) Decreased expression of the insulin responsive glucose transporter in diabetes and fasting. Nature 340:70-72

10. Sivitz WI, DeSautel SL, Kayano T, Bell GI, Pessin JE (1989) Regulation of glucose transporter messenger RNA in insulindeficient states. Nature 340: 72-74

11. Kosaki A, Kuzuya H, Yoshimasa Y, Yamada K, Okamoto M, Nishimura H, Kakehi T, Takeda J, Seino Y, Imura H (1988) Regulation of glucose-transporter gene expression by insulin in cultured human fibroblasts. Diabetes 37: 1583-1586

12. Garvey WT, Huecksteadt TP, Lima FB, Birnbaum MJ (1989) Expression of a glucose transporter gene cloned from brain in cellular models of insulin resistance: dexamenthasone decreases transporter mRNA in primary cultured adipocytes. Mol Endocrinol 3: 1132-1141

13. Rollins BJ, Morrison ED, Usher P, Flier JS (1988) Plateletderived growth factor regulates glucose transporter expression. $J$ Biol Chem 263: 16523-16526

14. Hiraki Y, Rosen OM, Birnbaum MJ (1988) Growth factors rapidly induce expression of the glucose transporter gene. $\mathbf{J}$ Biol Chem 263: 13655-13662

15. Maher F, Clark S, Harrison LC (1989) Chronic stimulation of glucose transporter gene expression in L6 myocytes mediated via the insulin-like growth factor-1 receptor. Mol Endocrinol 3: 2128-2135

16. Walker PS, Donovan JA, Ness BG van, Fellows RE, Pessin JE (1988) Glucose-dependent regulation of glucose tranport activity, protein, and mRNA in primary cultures of rat brain glial cells. J Biol Chem 263: 15 594-15601

17. Walker PS, RamlaI T, Donovan JA, Doering TP, Sandra A, Klip A, Pessin JE (1989) Insulin and glucose-dependent regulation of the glucose transport system in the rat L6 skeletal muscle cell line. J Biol Chem 264: 6587-6595

18. D'Amore T, Lo TCY (1986) Hexose transport in L6 rat myoblasts. 1. Rate-limiting step, kinetic properties and evidence for two systems. J Cell Physiol 127: 95-105

19. D'Amore T, Cheung MO, Duronio V, Lo TCY (1986) Stimulation of hexose transport in L6 rat myoblasts by antibody and by glucose starvation. Biochem J 238: 831-836

20. Sasson S, Cerasi E (1986) Substrate regulation of the glucose transport system in rat skeletal muscle. Characterisation and kinetic analysis in isolated soleus muscle and skeletal muscle cells in culture. J Biol Chem 261: 16827-16833

21. Kletzien RF, Perdue JF (1975) Induction of sugar transport in chick embryo fibroblasts by hexose starvation. Evidence for transcriptional regulation of transport. J Biol Chem 250: 593-600

22. Franchi A, Silvestre P, Pouyssegur J (1978) "Carrier activation" and glucose transport in Chinese hamster fibroblasts. Biochem Biophys Res Commun 85: 1526-1534 
23. Germinario RJ, Rockman H, Oliveira M, Manuel S, Taylor M (1982) Regulation of sugar transport in cultured diploid human skin fibroblasts. J Cell Physiol 112: 367-372

24. Rosen OM, Smith CJ, Fung C, Rubin CS (1978) Development of hormone receptors and hormone responsiveness in vitro. Effect of prolonged insulin treatment on hexose uptake in 3T3-L1 adipocytes. J Biol Chem 253: 7579-7583

25. Putten JPM van, Krans HMJ (1985) Glucose as a regulator of insulin-sensitive hexose uptake in $3 \mathrm{~T} 3$ adipocytes. J Biol Chem 260: 7996-8001

26. Sasson S, Edelson D, Cerasi E (1987) In vitro autoregulation of glucose utilization in rat soleus muscle. Diabetes 36: 1041-1046

27. Young DA, Uhl JJ, Cartee GD, Holloszy JO (1986) Activation of glucose transport in muscle by prolonged exposure to insulin. Effects of glucose and insulin concentrations. J Biol Chem 261: 16049-16053

28. Richter EA, Hansen BF, Hansen SA (1988) Glucose-induced insulin resistance of skeletal muscle glucose transport and uptake. Biochem J 252: 733-737

29. Yamada K, Tillotson LG, Isselbacher KJ (1983) Regulation of hexose carriers in chicken embryo fibroblasts. Effect of glucose starvation and role of protein synthesis. J Biol Chem 258: 97869792

30. Shawver LK, Olson SA, White MK, Weber MJ (1987) Degradation and biosynthesis of the glucose transporter protein in chicken embryo fibroblasts transformed by the src oncogene. Mol Cell Biol 7: 2112-2118

31. Lemmon SK, Sens DA, Buse MG (1985) Insulin stimulation of glucose transport and metabolism in a human Wilms' tumorderived myoblast-like cell line: modulation of hormone effects by glucose deprivation. J Cell Physiol 125: 456-464

32. Pessin JE, Tillotson LG, Yamada K, Gitomer W, Carter-Su C, Mora R, Isselbacher KJ, Czech MP (1982) Identification of the sterospecific hexose transporter from starved and fed chicken embryo fibroblasts. Proc Natl Acad Sci USA 79: 2286-2290

33. Haspel HC, Wilk EW, Birnbaum MJ, Cushman SW, Rosen OM (1986) Glucose deprivation and hexose transporter polypeptides of murine fibroblasts. J Biol Chem 261: 6778-6789

34. Yaffe D (1968) Retention of differentiation potentialities during prolonged cultivation of myogenic cells. Proc Natl Acad Sci USA 61:477-483

35. Gough NM (1988) Rapid and quantitative preparation of cytoplasmic RNA from small numbers of cells. Anal Biochem 173: 93-95

36. Pepinsky RB, Sinclair LK (1986) Epidermal growth factor-dependent phosphorylation of lipocortin. Nature $321: 81-84$

37. Haspel HC, Rosenfeld MG, Rosen OM (1988) Characterization of antisera to a synthetic carboxyl-terminal peptide of the glucose transporter protein. J Biol Chem 263:398-403

38. Klip A, Logan WJ, Li G (1982) Hexose transport in L6 muscle cells. Kinetic properties and the number of $\left[{ }^{3} \mathrm{H}\right]$ cytochalasin $B$ binding sites. Biochim Biophys Acta 687:265-280
39. Germinario RI, Michaelidou A (1986) Hexose transport after glucose refeeding of glucose-starved human fibroblasts. 1 . The effects of tunicamycin and cycloheximide; 2 . Insulin binding and action. Biochem Biophys Res Commun 140: 844-849

40. Gershman H, Robbins PW (1981) Transitory effects of glucose starvation on the synthesis of dolichol-linked oligosaccharides in mammalian cells. J Biol Chem 256:7774-7780

41. Rearick JI, Chapman A, Kornfeld S (1981) Glucose starvation alters lipid-linked oligosaccharide biosynthesis in chinese hamster ovary cells. J Biol Chem 256: 6255-6261

42. Baumann H, Jahreis GP (1983) Glucose starvation leads in rat hepatoma cells to partially N-glycosylated glycoproteins including $\alpha_{1}$-acid glyocoproteins. J Biol Chem 258: 3942-3949

43. Haspel HC, Birnbaum MJ, Wilk EW, Rosen OM (1985) Biosynthetic precursors and in vitro translation products of the glucose transporter of human hepatocarcinoma cells, human fibroblasts, and murine preadipocytes. J Biol Chem 260: 7219-7225

44. Haspel HC, Revillame J, Rosen OM (1988) Structure, biosynthesis, and function of the hexose transporter in Chinese hamster ovary cells deficient in $\mathrm{N}$-acetylglucosaminyltransferase 1 activity. J Cell Physiol 136: 361-366

45. Salter DW, Cook JS (1976) Reversible independent alterations in glucose transport and metabolism in cultured human cells deprived of glucose. J Cell Physiol 89: 143-156

46. Musliner TA, Chrousos GP, Amos H (1977) Transport enhancement and reversal: glucose and 3-0-methylglucose. J Cell Physiol 91: 155-168

47. Ullrey DB, Franchi A, Pouyssegur J, Kalckar HM (1982) Downregulation of the hexose transport system: metabolic basis studied with a fibroblast mutant lacking phosphoglucose isomerase. Proc Natl Acad Sci USA 79: 3777-3779

48. Chen SR, Lo TCY (1988) Cytochalasin B as a probe for the two hexose-transport systems in rat $\mathbf{L} 6$ myoblasts. Biochem $\mathbf{J} 251$ : $63-72$

49. Morgan MJ, Faik P (1986) The utilization of carbohydrates by animal cells. An approach to their biochemical genetics. In: Morgan MJ (ed) Carbohydrate metabolism in cultured cells. Plenum. Press, New York, pp 29-75

Received: 19 February 1990

and in revised form: 22 May 1990

Prof. L.C. Harrison

Burnet Clinical Research Unit

Walter and Eliza Hall Institute of Medical Research

Royal Melboume Hospital Post Office

Parkville, Victoria, 3050

Australia 